\title{
Ageing and intergenerational family ties in Arab countries
}

\author{
N.M. Kronfol, ${ }^{1,2}$ A. Rizk ${ }^{3}$ and A.M. Sibai ${ }^{2,3}$
}

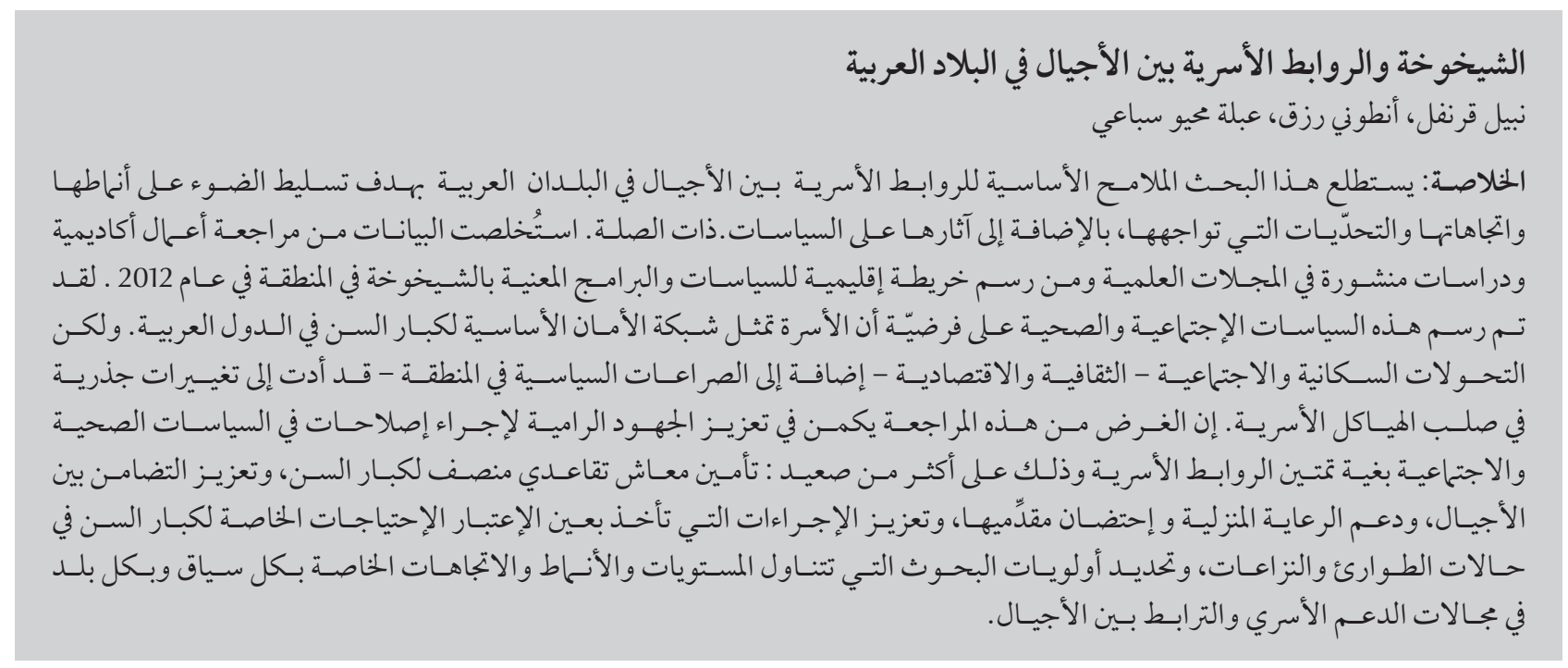

ABSTRACT This paper explores the dominant issues in intergenerational ties in Arab countries with a view to highlighting patterns, trends and challenges as well as policy implications. The data were drawn from a review of scholarly work and published literature in Arab countries and from a regional mapping of ageing policies and programmes in 2012. Social and health ageing policies in the region have been set with the premise that the family represents the core safety net for older Arabs. Yet demographic, sociocultural and economic transitions, as well as political conflict in the Arab world, are bringing profound changes to familial structures. This review feeds into efforts to promote health and social reforms that approach intergenerational solidarity from several fronts: providing equitable old-age income security, fostering cross-generational interactions, embracing caregivers and home-based care, promoting age-responsive actions in emergencies and conflicts, and prioritizing context- and country-specific research on the levels, types and trends in intergenerational and familial support.

\section{Vieillissement et liens familiaux intergénérationnels dans les pays arabes}

RÉSUMÉ Le présent article étudie les questions dominantes concernant les liens intergénérationnels dans les pays arabes afin de dégager les caractéristiques, les tendances et les difficultés ainsi que les implications politiques. Les données sont issues d'un examen des travaux académiques et des publications dans les pays arabes ainsi que d'une cartographie régionale des politiques et programmes sur le vieillissement en 2012. Les politiques sociales et sanitaires sur le vieillissement dans la Région ont été établies à partir du postulat selon lequel la famille représente le filet de sécurité essentiel pour les Arabes plus âgés. Toutefois, les transitions démographiques, socioculturelles et économiques, ainsi que les conflits politiques dans le monde arabe sont sources de profonds changements pour les structures familiales. Cet examen contribue aux actions visant à promouvoir des réformes sanitaires et sociales qui relèvent de la solidarité intergénérationnelle sur plusieurs plans : garantir une pension équitable pour les personnes âgées, favoriser les interactions entre les générations, prendre en compte les aidants et les soins à domicile, promouvoir des actions respectueuses de l'âge dans les situations d'urgence et de conflit, et établir un ordre de priorité pour la recherche propre aux pays et aux contextes sur les niveaux et les types de soutien familial et intergénérationnel ainsi que les tendances en la matière. 


\section{Introduction}

Permeated by a moral code of conduct to honour and respect elders, extended family structures have long played a key role in the care and well-being of older people in the Arab world. To varying degrees, older persons in most Arab societies have traditionally lived in multi-generational households where adult children, spouses and other family members can be relied on for material support and care (1). The constitutions of many Arab states are a testament to the privileged position of the family as the basic unit of society, while religious institutions, in varying settings, consider themselves promoters of family integrity (2). These informal family and community-based care systems may have contributed to lessening the pressure on Arab governments to establish formal public welfare systems that provide care and safety nets for their older residents. However, demographic transitions, shifts in social norms, and economic pressures, as well as medical advances and the ensuing changes in health patterns in later life, are triggering various forms of estrangement from the traditional family configuration and have resulted in fundamental changes in old-age care. This has come to be problematized as "the fraying in the social cohesion between generations" (3-5).

International research has varied in its characterization of intergenerational solidarity. While studies show that support, including financial exchanges, is likely to flow upwards from adult children to older parents $(6,7)$, other findings show that financial support continues to flow from older parents towards adult children, at least until parents begin to undergo a decline in health $(8,9)$, with categorically different filial norms across populations (6). Deindl and Brandt noted that when generous provision of government-sponsored social services exists and children have to provide less financial support, other kinds of voluntary or emotional support are encouraged (10).

Very little research has been conducted in Arab countries on the levels, types and trends in familial support vis-à-vis the growing economic constraints and limited public health and social services for older persons. Scholarly work has yet to elucidate how intergenerational ties differ within and across Arab countries, in a region where support tends to flow on a reciprocal basis between the young and old (1). Within the changing context of growing economic and political crisis in several settings in the region, this paper explores the shifting dynamics of intergenerational solidarity in Arab countries to shed light on possible future implications and to illustrate, to the extent that the data allow, the plight of caregiving and caregivers in Arab countries. The data and information presented in this paper are drawn from the published literature as well as from a comprehensive region-wide mapping of ageing policies and programmes in Arab countries conducted by the authors in 2012 (Sibai AM, Rizk A, Kronfol KM. Ageing in the Arab region: trends, implications and policy options. United Nations Population Fund, Economic and Social Commission of Western Asia and the Center for Studies on Aging, Lebanon, unpublished report).

\section{Intergenerational cohesion in Arab countries}

Kagitcibasi et al., in a comparison of intergenerational relationships in the region and elsewhere, noted that intergenerational relationships and solidarity constitute the core of family dynamics and stated that a key aspect of these relations lies in "the degree of support that is expected, aspired, considered proper, assumed and/or actually provided" (11). Three main indicators are examined below to appraise the cohesion between the generations in Arab countries: legislation, policies and programmes related to intergenerational solidarity; living arrangements and co-residence patterns; and exchanges between generations.

\section{Legislation, policies and programmes}

The 2002 Arab Plan of Action on Ageing endorsed intergenerational solidarity as the cornerstone of social development and urged Member States of the United Nations to develop initiatives that bridge the generational gap towards mutual benefit and experience-sharing (12). As such, social and health laws and policies in many countries of the Arab region have been instituted with a vested value in the centrality of familial support, where legislation is intricately connected with councils and directorates of family affairs, most notably in Gulf Cooperation Council (GCC) countries. The Permanent Constitution of the State of Qatar, Article 21, for example, explicitly states that "the family founded on religion, morality and patriotism is the basis of the Qatari society" (1). Also, the ministerial body involved with ageing affairs in Morocco is situated in the Office of the Family, Children and the Elderly, and Syria Arab Republic's National Committee on Ageing is positioned in the Commission for Family Affairs. Likewise, Jordan's comprehensive strategy for the welfare of the aged has been prepared in close cooperation with the National Council on Family Affairs.

In the same spirit, several countries in the region have instituted policies and programmes that foster intergenerational solidarity, such as young adults taking care of older persons (as in Bahrain, Kuwait, Palestine and Sudan) and families hosting older people in need (as in Bahrain and Tunisia). Furthermore, laws and policies that hold kin responsible for older relatives exist in 
Bahrain, Jordan, Kuwait, Libya, Morocco, Palestine, Qatar and Yemen and are under review in Oman (13). In Morocco, articles 484-486 of the penal code heighten the penalties for felonies and misdemeanours committed against older persons, and the Kuwaiti law (Act No 11 of 2007) provides for sentences of 1-year imprisonment for negligence towards older family members (14). In Tunisia, social protection for older people is legally assured through Law 94114 (passed in October 1994) which strengthens intergenerational solidarity and family integration through ensuring older people continue to live in their homes, or in the homes of host families, as well as reducing social exclusion and facilitating access to health care and social assistance (15).

\section{Living arrangements and co- residence}

Co-residence is one of the means by which Arab families fulfil the support owed to their older relatives. Population data from several countries suggest increasing heterogeneity, by place and person, in the norms that drive living arrangements and intergenerational support. Although scholarly studies on Arab households remain sparse, the literature on family systems and living arrangements cites modernization and urbanization as drivers towards increasing nuclear family structures and the fraying of multi-generational households. Olmsted conducted a historical comparison to elucidate the changes in household formations in Arab countries and concluded that, while patterns had varied considerably across communities, extended family households occurred historically more frequently in the Syrian Arab Republic and Yemen, and shifts in social norms and cultural and economic pressures have contributed towards changing intergenerational living in many countries including Lebanon, Egypt and Yemen (16). Exacerbated by local and regional population movements resulting from industrialization and modernization, this may have translated into a weakening of family ties and changing gender roles (17). However, the extended family in Arab societywhereby strong and highly gendered forms of co-residence and transfers remain between generations - has not yet completely dissolved. In Egypt, for example, older parents have a vested interest in continuing to support married daughters, who often live in the same neighbourhoods, village or building as their parents; and upward material transfers are expected from adult sons who remain a form of old-age insurance (18). In some countries, such as Qatar, institutional steps have been taken towards ensuring close familial residence, such as providing free housing on condition that extended families live in close proximity (19).

Of all the various living arrangements, living alone is the most ambivalent category with respect to the welfare of older persons. Solitary living may indicate social isolation and exclusion; however, it may also signify financial and psychological independence (20). In Arab countries, very low rates of solitary living are reported from the oilrich country of Kuwait (1.2\%) and the poorer communities in Khartoum, Sudan $(2 \%)$. Between $5 \%$ and $7 \%$ of older men and women live alone in Egypt and Jordan (20). By comparison, the proportion of older persons living alone in Lebanon is relatively high (close to $10 \%$ ). While the drivers for these differences remain unclear, studies on solitary living are increasingly warranted in this region where older persons living alone defy the customary Arab arrangement of intergenerational co-residence and support.

\section{Exchanges between generations}

While data on material exchanges across generations are scarce in Arab countries, some information is available from the national Pan Arab Project for Family Health studies conducted in
Algeria, Lebanon and Palestine and from the Survey of Health, Ageing and Retirement in Saudi Arabia, as well as a number of specialized small-scale studies in Tunisia and Egypt. Data show that older persons are not only recipients of care but also provide support within the family (between 34\% and $40 \%$ of older persons in Algeria, Lebanon and Palestine provide help in child-rearing and domestic chores) and extend financial support to their children and other family members (between 26\% and 61\%) (7). Furthermore, data from Lebanon show that financial support for older parents is received from adult children ( $54.1 \%$ of older men and $68.6 \%$ of older women), and that this percentage increases consistently with age, approaching $72 \%$ of those aged 80 years and over (1). Research from Egypt reveals that older parents and adult children maintain frequent contact, creating expectations of and opportunities for economic exchange by which older fathers are disproportionate givers and older mothers are disproportionate receivers of economic transfers (18).

The international literature shows that, although the magnitude of intergenerational financial support from adult children to their elderly parents has declined in some countries, it remains significant when the health or disability status of the older person falters $(8,9)$. This may differ greatly, however, by country, depending on the availability of health and social services and pension systems. It may also differ by class - whereby economically-independent older adults would require less financial support-as well as by sex-whereby older women are less able to mobilize resources than older men. Concurrently, and despite changing family patterns, older persons often assume a key role as a social safety net for adult children and their families, and hence should not be seen only as dependent and passive receivers of support and care. 


Challenges to
intergenerational
cohesion

\section{Demographic realities}

The profound demographic transitions that have been taking place in the Arab world over the past 5 decades, notably the impressive declines in fertility rates, have altered intergenerational cohesion on several fronts. While changes in fertility patterns are heralded as indicators of economic development and modernization, the consequences include a shift towards smaller, nuclear families and changes in household structures and intergenerational living arrangements $(21-23)$. This is further exacerbated by a pattern of substantial outwards migration of youth seeking better employment opportunities and safer havens elsewhere. While not well-documented, some countries are currently facing counter-waves of return migration, a flow of older retired workers back to their original homeland, having worked and served in the host country for decades with no prospects of becoming a national (24). Population dynamics and the subsequent changes in dependency ratios signify that the responsibility of the adult workforce is increasingly shifting from the support of children to the simultaneous support of children and older persons (25). This is most clearly seen through the old-age dependency ratio, defined as the number of persons aged 65 years and above per 100 persons between the ages of 15-64 years and measures the capacity of a working economy to sustain non-working older persons. Currently, the Arab region includes among the lowest old-age dependency ratios worldwide: between 1 in Qatar and the United Arab Emirates (UAE) and 11 in Lebanon. However, by 2030 , this ratio is expected to rapidly increase in some GCC countries (such as Bahrain, Qatar and the UAE) and more than double in some others (Table 1) (26).

\begin{tabular}{|c|c|c|c|}
\hline \multicolumn{4}{|c|}{$\begin{array}{l}\text { Table } 1 \text { Trends and projections in old-age dependency ratios in Arab countries } \\
(\mathbf{1 9 8 0 - 2 0 3 0 )}\end{array}$} \\
\hline \multirow[t]{2}{*}{ Country } & \multicolumn{3}{|c|}{ Dependency ratio $(\%)^{a}$} \\
\hline & 1980 & 2010 & 2030 \\
\hline Algeria & 8 & 7 & 13 \\
\hline Bahrain & 3 & 3 & 12 \\
\hline Comoros & 6 & 5 & 6 \\
\hline Djibouti & 4 & 5 & 7 \\
\hline Egypt & 6 & 8 & 13 \\
\hline Iraq & 8 & 6 & 6 \\
\hline Jordan & 7 & 7 & 8 \\
\hline Kuwait & 3 & 4 & 14 \\
\hline Lebanon & 10 & 11 & 17 \\
\hline Libya & 4 & 7 & 11 \\
\hline Mauritania & 5 & 5 & 6 \\
\hline Morocco & 8 & 8 & 15 \\
\hline Oman & 5 & 4 & 11 \\
\hline Palestine & 5 & 5 & 7 \\
\hline Qatar & 2 & 1 & 5 \\
\hline Saudi Arabia & 6 & 4 & 9 \\
\hline Somalia & 6 & 5 & 6 \\
\hline Syria & 7 & 7 & 11 \\
\hline Sudan & 6 & 6 & 8 \\
\hline Tunisia & 7 & 10 & 18 \\
\hline United Arab Emirates & 2 & 1 & 8 \\
\hline Yemen & 5 & 5 & 5 \\
\hline
\end{tabular}

Source: United Nations Department of Economic and Social Affairs, 2012 (26), using medium variants ${ }^{a}$ Dependency ratios are calculated by the source through the following formula (number of persons aged 65 years and above per 100 persons between the ages of 15-64 years) of the de facto population.

\section{Sociocultural transitions}

Religious moral codes that emphasize honour, respect and affection towards older parents in the Arab region influence, to a large extent, the system of intergenerational ties and facilitate material exchanges. This allows for the pooling and sharing of resources and creates conditions that reinforce emotional and psychological support (27). Provision of care to older persons has traditionally fallen on daughters and daughter-in-laws in Arab countries (17) and worldwide (28). However, a shift in these norms has been documented in a number of countries of the region. The traditional nuptial tenets of the Arab countries - generally characterized by early marriage for women, universal marriage for both sexes and large age differences between spouses-have in many respects changed greatly over the past century (29) in a drastic shift that Tabutin and Schoumaker call the "marriage revolution" (30). This, and the increased entry of women in the workforce, may contribute towards unravelling the existing multigenerational household pattern and necessitate changes in familial roles, which carry a set of gendered duties and responsibilities for family members, including the young and old.

\section{Economic and health challenges}

Economic crises have left several Arab countries struggling to provide work opportunities for their growing labour forces. The proportion of unemployed is particularly high among 
youth $(25 \%)$ and is especially critical in North African countries and in poor and conflict-ridden areas (31). These economic constraints have made crossgenerational and inter-family financial dependency a necessity, especially when augmented by lack of sufficient retirement benefits and inadequate oldage health insurance. However, the capacity of working-age family members to care simultaneously for older persons and younger dependants is becoming increasingly strained, particularly in the context of high unemployment, making more efficient and universal government-sponsored health and social care policies and programmes an urgent necessity (32). Older persons who are single, widowed or childless (particularly women) face an even higher risk of destitution $(33,34)$.

At the same time, when social protection nets and universal health systems are either stagnant or regressing in some Arab countries (35), increasing longevity and shifts in disease patterns towards degenerative chronic diseases absorb families' savings. Hypertension, heart diseases, diabetes, arthritis and chronic back pain appear to be the leading causes of morbidity among older age groups (36) and the percentage of older persons suffering from at least one chronic disease ranges from as low as $13.1 \%$ in Djibouti to a high estimate of 63.8\% in Lebanon, with a large number of countries having rates above $40 \%$ (Pan Arab Project for Family Health, League of Arab States. Analysis of survey data, unpublished data, 2008). Health care costs in the older age cohorts is much higher than for the younger population, with the average cost per capita doubling with each 10year age increase beyond the age of 65 years (37). These two inextricably related issues - ageing and chronic disease - create challenges for public health and clinical care in settings already faced with scarce recourses, and necessitate changes in health-care systems and services (38).

\section{Pension systems in Arab countries}

Pension systems were introduced to the Arab world as a sustainable solution for older people's welfare, and laws regulating social security and pensions were drafted and implemented in the region from as early as 1950 in Egypt to as late as 1991 in Oman. Despite major economic changes and geopolitical developments, some countries have never made any revisions to their pension laws since their initiation (e.g. Bahrain, Lebanon and Syrian Arab Republic), while others continue to introduce frequent updates, with the latest being introduced in Jordan in 2010 (Table 2) $(39,40)$. Furthermore, owing to low pension contribution rates and increasing life expectancy, some funds suffer from very low reserves and are at risk of using government reserves to pay pension dues (41).

Pension systems in the region also tend to be highly fragmented, with wide variations in the level of basic benefits for retirees. Public servants enjoy better social and health insurance coverage as well as better privileges and benefits than those in the private sector (Sibai AM, Rizk A, Kronfol KM, unpublished report). On the other hand, the self-employed and those in the informal sector almost never qualify for old-age pension plans; this adversely affects agricultural workers and many women who fall out of the social security umbrella (Table 2). It is estimated that only $34 \%$ of the labour force in the region are enrolled in pension schemes (41). Because of precarious safety nets, economic insecurity becomes a main driver for older people in some Arab countries to continue to work after the legal age of retirement. For example, between $37 \%$ and $65 \%$ of older men aged 60-69 years and between 24\% and $47 \%$ of those aged $70-79$ years in Egypt, Jordan, Lebanon, Palestine and Yemen continue to be involved in the workforce (42). In contrast, retirement is the norm in developed countries.

\section{Conflicts and political instabilities}

Owing to a conflagration of internal and external factors, a number of Arab countries are caught up in long-standing wars and conflicts (e.g. Iraq, Lebanon, Palestine, Somalia and Sudan), and some others have more recently been affected by civil disturbances, political crisis or major conflicts (e.g. Tunisia, Libya, Egypt, Yemen and Syrian Arab Republic). The consequences of these conflicts permeate almost all segments of society, with adverse effects on populations that include violent deaths and injuries, loss of property and assets, and displacement, as well as damage to essential infrastructure and welfare systems (43). The adverse outcomes of conflicts are especially disruptive to older persons, who may face untimely transitions into widowhood, solitary living, forced retirement and displacement (44). Tensions and political instabilities also exacerbate social and economic vulnerabilities, pushing youth to emigrate and hence further diminishing opportunities for co-residence and intergenerational exchange. For instance, research from Lebanon has shown that the proportion of older women living alone in the Southern governorate, which has been most exposed to recurrent occupations, wars and instabilities, exceeds $20 \%$, and is around twice the national average (45). Furthermore, the more recent Syrian crisis, with its huge levels of population displacement and transnational migration, is highlighting the perilous health profile of older refugees (46) and their heightened vulnerabilities stemming from disruption to the social fabric and the loss of family ties, homes and property (47). In the absence of ageresponsive actions by relief agencies and nongovernmental organizations in planning for, responding to, and recovering from emergencies, older persons are easily overlooked during conflicts and disasters. 


\begin{tabular}{|c|c|c|c|c|}
\hline \multirow[t]{2}{*}{ Country } & \multicolumn{2}{|c|}{ Pension laws } & \multirow[t]{2}{*}{ Administrative organization } & \multirow[t]{2}{*}{ Pension exclusions } \\
\hline & $\begin{array}{l}\text { Year first } \\
\text { drafted }\end{array}$ & $\begin{array}{l}\text { Year last } \\
\text { updated }\end{array}$ & & \\
\hline Bahrain & 1976 & - & Ministry of Finance & $\begin{array}{l}\text { Household and agricultural workers, } \\
\text { casual workers, temporary non-citizen } \\
\text { workers }\end{array}$ \\
\hline Egypt & $1950 / 5$ & 1980 & Ministry of Finance & - \\
\hline Jordan & 1978 & 2010 & Social Security Corporation & $\begin{array}{l}\text { Civil servants hired before } 1995 \text {, military } \\
\text { staff hired before } 2003 \text {, casual labourers }\end{array}$ \\
\hline Kuwait & $1976 / 7$ & - & Ministry of Finance & - \\
\hline Lebanon & 1963 & - & Ministry of Labor & $\begin{array}{l}\text { Temporary agricultural employees, self- } \\
\text { employed persons }\end{array}$ \\
\hline Libya & 1957 & 1980/1 & Social security committees & - \\
\hline Morocco & 1959 & 2004 & $\begin{array}{l}\text { Ministry of Employment and } \\
\text { Vocational Training }\end{array}$ & Self-employed persons \\
\hline Oman & $1991 / 2$ & - & Ministry of Manpower & $\begin{array}{l}\text { Foreign workers, household workers, } \\
\text { self-employed persons, artisans }\end{array}$ \\
\hline Saudi Arabia & 1969 & 2001 & Ministry of Labour & $\begin{array}{l}\text { Household and agricultural workers, } \\
\text { fishermen, family labour, foreign } \\
\text { workers }\end{array}$ \\
\hline Sudan & 1974 & 1990 & $\begin{array}{l}\text { Ministry of Welfare and Social } \\
\text { Security }\end{array}$ & $\begin{array}{l}\text { Household workers, home-based } \\
\text { workers, farmers and foresters, unpaid } \\
\text { apprentices }\end{array}$ \\
\hline Syrian Arab Republic & 1959 & - & Ministry of Social Affairs; Labour & $\begin{array}{l}\text { Temporary workers, household } \\
\text { workers, self-employed persons }\end{array}$ \\
\hline Tunisia & 1960 & 1995 & Ministry of Social Affairs; Solidarity & Prisoners working in prison workshops \\
\hline Yemen & 1980 & 1991 & $\begin{array}{l}\text { Separate boards of directors } \\
\text { supervise }\end{array}$ & $\begin{array}{l}\text { Casual workers, self-employed persons, } \\
\text { agricultural workers, seamen, fishermen }\end{array}$ \\
\hline
\end{tabular}

Source: United States Social Security Administration 2011 (39,40).

\section{The plight of caregivers}

Family members, typically middle-aged daughters as well as daughters-in-law, continue to play the major role of caregiving to older relatives in Arab societies. With time, caregivers may develop a personal sense of satisfaction for fulfilling their obligations towards the aged. However, caregiving for a cohabiting frail and disabled older person carries significant emotional, physical and financial strains, and lost work and leisure opportunities, that may cause serious health problems for the caregivers themselves (48). A study conducted in Lebanon found that the likelihood of health risks for the caregiver increased as the degree of functional impairment and frequency of depressive and disruptive behaviour of the cared-for relative increase (49). Some countries in the region have policies and programmes that promote the provision of social support to the caregivers of older persons, including the provision of short-term temporary relief (respite services). Algeria provides financial support for families taking care of older persons, and Bahrain, Egypt and Lebanon include initiatives to train caregivers and build the capacities of companions to older persons in home care. Additionally, Jordan's National Committee for Family Affairs has prepared a booklet geared to caregivers that addresses many of the needed health and social skills.

Nevertheless, the difficulties of caring for older persons remain underresearched across Arab countries and require closer investigation. It is notable, however, that owing to these strains, Arab families in a number of countries are increasingly opting for a new form of in-home care by full-time, live-in foreign domestic workers, mainly from South-East Asian and African countries. This way of ensuring full-time caregiving is highly classed, gendered and racialized and is linked to global and local economic and social inequalities and the "feminization and colorization" of labour in longterm care (50), where the employing families tend to be wealthy nationals and the migrant caregivers tend to be women from Global South countries. Migrant workers play the role of both domestic worker and companion, providing long-term care to older people who are dependent on help in activities of basic daily living (48), as well as maintaining the family orientation for elder care and contributing to lower rates of institutionalization for older people. However, they may also be subject to stringent and discriminatory 
labour practices and sponsorship ( $k a-$ fala) systems (51) and lack formal qualifications for elder care. While the Arab region is undergoing a period of economic crisis with high rates of youth unemployment, little is done to make employment in social and health care for older adults appealing to the national workforce.

\section{Concluding remarks}

Demographic, sociocultural and economic transitions, as well as political conflict in the Arab world, have brought about profound changes to intergenerational familial ties. Yet, the family continues to be the main social unit for the care of older Arabs. This review highlights the urgent need for data that are capable of keeping abreast of rapid demographic, socioeconomic and health transitions and informing evidence-based policy. The availability of information does not guarantee success for policies and programmes; however, an absence of data almost always ensures failure
To facilitate the transition into ageing societies, Arab countries are called upon to approach intergenerational solidarity from several fronts:

- providing equitable old-age income security, accessible and affordable health and social services, and implementation of poverty-reduction strategies that would contribute to relieving the economic burden from Arab families;

- fostering cross-generational interactions and exchanges (e.g. promoting close residence between older adults and children, supporting younger families hosting older people);

- promoting home-based care services (e.g. mobile units, respite services, financial incentives to caregivers and for home-based palliative care) and embracing caregivers as beneficiaries of care;

- promoting age-responsive actions in times of emergencies, conflicts and disasters; and

- prioritizing context- and countryspecific research on the levels, types and trends in intergenerational and familial support and exchanges in the light of ongoing demographic, social, health and economic transitions.

In spite of the challenges presented here, population ageing also presents opportunities. Older people are a resource for their families and communities, they possess a wealth of knowledge and are a repository of social capital, and many remain active participants in the formal or informal workforce, contributing to the socioeconomic development of their societies. While there is no single policy or measure that is a panacea to all problems, there is a need for a paradigm shift in the approach to the issue of ageing in countries of the Arab region to one that reaps the rewards of this longevity dividend: the additional years lived (52). As such, investing in older persons' accumulated life experience and capabilities and recognizing the societal and economic opportunities associated with ageing may present untapped opportunities for improving intergenerational solidarity and family ties.

\section{Funding: None}

Competing interests: None declared.

\section{References}

1. Sibai AM, Yamout R. Family-based old-age care in Arab countries: between tradition and modernity. In: Gorth $\mathrm{H}$ and SousaPoza A, editors. Population dynamics in Muslim countries: assembling the jigsaw. Berlin: Springer Heidelberg; 2012.

2. Joseph S, Slyomovics S. Women and power in the Middle East. Philadelphia (PA): University of Pennsylvania Press; 2001.

3. Bengtson VL, Olander EB, Haddad AA. The "generation gap" and ageing family members: Toward a conceptual model. In: Gubrium JF, editor. Time, roles, and self in old age. New York: Human Sciences Press; 1976.

4. Roberts REL, Richards LN, Bengtson VL. Intergenerational solidarity in families: Untangling the ties that bind. In: Pfeifer SK, Sussman MB, editors. Marriage and family review. Binghamton (NY): Haworth Press; 1991.

5. Katz R, Lowenstein A, Phillips J, Daatland SO. Theorizing intergenerational family relations: solidarity, conflict, and ambivalence in cross-national contexts. In: Acock AC, Bengtson $\mathrm{VL}$, Allen KR, Dilworth-Anderson P, Klein DM, editors. Sourcebook of family theory and research. Thousand Oaks (CA): SAGE Publications; 2005.

6. Lin J, Yi C. Filial norms and intergenerational support to aging parents in China and Taiwan. Int J Soc Welf. 2011;20:S109-20.

7. Ajrouch KJ, Yount K, Sibai AM, Roman P. A gendered perspective on well-being in later life: Algeria, Lebanon, and Palestine.
In: McDaniel S, Zimmer Z, editors. Global ageing in the 21st century. Farnham, UK: Ashgate Publishing; 2013.

8. Lowenstein A, Daatland SO. Filial norms and family support in a comparative cross-national context: evidence from the OASIS study. Ageing Soc. 2006;26:203-23.

9. Swartz TT. Intergenerational family relations in adulthood: Patterns, variations, and implications in the contemporary United States. Annu Rev Sociol. 2009;35:191-212.

10. Deindl C, Brandt M. Financial support and practical help between older parents and their middle-aged children in Europe. Ageing Soc. 2011;31(4):645-62.

11. Kagitcibasi C, Bilge A, Aysesim D. Intergenerational relationships in the family: ethnic, socioeconomic, and country variations in Germany, Israel, Palestine, and Turkey. J Cross Cult Psychol. 2010;41:652-70.

12. Arab Plan of Action on Ageing to the year 2012. New York (NY): United Nations Economic and Social Commission of Western Asia; 2002.

13. Kronfol NM, Sibai AM, RizkA. Ageing in the Arab region: trends, implications and policy options. New York (NY): Economic and Social Commission of Western Asia; 2014 (http://www. escwa.un.org/divisions/div_editor/Download.asp?table name $=$ divisions_other\&field_name $=\mid D \&$ File $I D=1588$, accessed 27 September 2014). 
14. National report submitted in accordance with paragraph 15(a) of the annex to Human Rights Council resolution 5/1. Kuwait. In: Eighth session of the Working Group on the Universal Periodic Review, Geneva, 3-14 May 2010. Geneva: United Nations Human Rights Council; 2010 (A/HRC/WG.6/8/KWT/1) (http://www.univie.ac.at/bimtor/dateien/kuwait_upr_2010_ report.pdf, accessed 27 September 2014).

15. Gouiaa R, Hajem S, Sibai AM, Hsairi M. Development of gerontology in Tunisia. In: Khavinson V, Anisimov V, editors. Encyclopedia: gerontology in Europe Part 1. Advances in Gerontology. 2015;28(1 Suppl.):73-7.

16. Olmsted J. Norms, economic conditions and household formation: a case study of the Arab world. Hist Fam. 2011;16(4):401-15

17. Olmsted JC. Gender, aging, and the evolving Arab patriarchal contract. Fem Econ. 2005;11(2):53-78.

18. Yount KM, Cunningham SA, Engelman M, Agree EM. Gender and marital transfers between older parents and children in Ismailia, Egypt. J Marriage Fam. 2012 Feb;74(1):116-31. PMID:22448075

19. Current status of the social situation, well-being, participation in development and rights of older persons worldwide. New York (NY): United Nations, Department of Economic and Social Affairs; 2011 (http://www.un.org/esa/socdev/ageing/ documents/publications/current-status-older-persons.pdf, accessed June 13 2014).

20. Tohme RA, Yount KM, Yassine S, Shideed S, Sibai AM. Socioeconomic resources and living arrangements of older adults in Lebanon: who chooses to live alone? Ageing Soc. 2011;31(1):1-17.

21. Khadr Z, El Zeini L. Families and households: headship and coresidence. In: Hopkins NS, editor. The new Arab family. Cairo Papers in Social Science. 2001;24(1/2):140-64.

22. Rashad H. Demographic transition in Arab countries: a new perspective. J Popul Res. 2000;17(1):83-101.

23. Mirkin B. Arab human development report 2011. Population levels, trends and policies in the Arab Region: challenges and opportunities. New York (NY): United Nations Development Programme; 2010 (http://www.arab-hdr.org/publications/ other/ahdrps/paper01-en.pdf, accessed 27 September 2014).

24. Sibai AM, RizkA, Kronfol NM. Aging in Lebanon: perils and prospects. J Med Liban. 2015 Jan-Mar;63(1):2-7. PMID:25906507

25. Saxena PC. Ageing and age-structural transition in the Arab countries: Regional variations, socioeconomic consequences and social security. Genus. 2008;64(12):37-74.

26. 2015 Revision of World Population Prospects. New York (NY) United Nations, Department of Economic and Social Affairs, Population Division; 2015 (http://esa.un.org/wpp/, 27 September 2015).

27. Palloni A, Pinto G, Wong R. Family support networks and population ageing conference. Paper presented at the seminar on Family support networks and population ageing, Doha, Qatar, 3-4 June 2009. Doha: Doha International Institute for Family Studies and Development and United Nations Fund on Population; 2009 (http://envejecimiento.sociales.unam. $\mathrm{mx}$ /articulos/family_support_networks2009.pdf, accessed 27 September 2015).

28. Stark A. Warm hands in cold age-on the need of a new world order of care. Fem Econ. 2005;11(2):7-36.

29. Carmichael S. Marriage and power: Age at first marriage and spousal age gap in lesser developed countries. Hist Fam. 2011;16:416-36.

30. Tabutin D, Schoumaker B. The demography of the Arab world and the Middle East from the 1950s to the 2000s: a survey of changes and a statistical assessment. Population (Paris) 2005;60(5-6):505-616.
31. Chaaban J. Job creation in the Arab economies: navigating through difficult waters. Arab Human Development Report Paper Series No 3. . New York (NY): United Nations Development Programme; 2010.

32. Social protection: a life cycle continuum investment for social justice, poverty reduction and sustainable development. Geneva: International Labour Organization; 2003.

33. Lund R, Due P, Modvig J, Holstein BE, Damsgaard MT, Andersen PK. Cohabitation and marital status as predictors of mortality-an eight year follow-up study. Soc Sci Med. 2002 Aug;55(4):673-9. PMID:12188471

34. Hughes ME, Waite LJ. Health in household context: living arrangements and health in late middle age. J Health Soc Behav. 2002 Mar;43(1):1-21. PMID:11949193

35. Saleh SS, Alameddine MS, Natafgi NM, Mataria A, Sabri B, Nasher J, et al. The path towards universal health coverage in the Arab uprising countries Tunisia, Egypt, Libya, and Yemen. Lancet. 2014 Jan 25;383(9914):368-81. PMID:24452045

36. Mokdad AH, Jaber S, Aziz MI, AlBuhairan F, AlGhaithi A, AlHamad NM, et al. The state of health in the Arab world, 1990-2010: an analysis of the burden of diseases, injuries, and risk factors. Lancet. 2014 Jan 25;383(9914):309-20. PMID:24452042

37. Roslyn Kunin and Associates Inc, editors. Population aging: economic and social dimensions. A paper prepared for the Business Council of British Columbia Outlook 2020 Project. Vancouver (BC): Business Council of British Columbia; 2009 (http://www.bcbc.com/content/548/2020_200909_Kunin_Aging.pdf, accessed 27 September 2015).

38. Kronfol N, Sibai AM, Raffoul M. Chronic diseases and aging in the Eastern Mediterranean Region: from research to policy and practice. Policy Brief, Issue 3. Beirut: Center for Studies on Aging; 2010.

39. Social security programs throughout the world. Africa. Washington (DC): United States Social Security Administration; 2011.

40. Social security programs throughout the world. Asia and the Pacific. Washington (DC): United States Social Security Administration; 2011.

41. Robalino D, Whitehouse E, Mataoanu A, Musalem A, Sherwood E, Sluchynsky O. Pensions in the Middle East and North Africa: time for change. Munich Personal RePEc Archive. Washington (DC): World Bank; 2005 (https://mpra.ub.unimuenchen.de/10448/1/MPRA_paper_10448.pdf, accessed 27 September 2015).

42. Yount KM, Sibai AM. The demography of ageing in Arab societies. In: Uhlenberg P, editor. International Handbook of Population Ageing. . Dordrecht, Netherlands: Springer; 2009.

43. Coutts A, Stuckler D, Batniji R, Ismail S, Maziak W, McKee M. The Arab Spring and health: two years on. Int J Health Serv. 2013;43(1):49-60. PMID:23527453

44. Sibai AM, Yount KM, Fletcher A. Marital status, intergenerational co-residence and cardiovascular and all-cause mortality among middle-aged and older men and women during wartime in Beirut: gains and liabilities. Soc Sci Med. 2007 Jan;64(1):64-76. PMID:17030373

45. Sibai AM, Sen K, Baydoun M, Saxena P. Population ageing in Lebanon: current status, future prospects and implications for policy. Bull World Health Organ. 2004 Mar;82(3):219-25. PMID:15112011

46. Chahda N, Sayah H, Strong J, Varady CJ. Forgotten voices: An insight into older persons among refugees from Syria in Lebanon. Beirut: Caritas Lebanon Migrant Center; 2013.

47. Gaps in the humanitarian response to the Syrian crisis for persons with disabilities and older people. 14 May-8 July 2013. 
First deployment report. HelpAge Inclusion Advisor secondment through Handicap International response to the Syrian crisis in Lebanon. London: HelpAge International; 2013.

48. Sibai AM. Older people in Lebanon: voices of the caregivers. Policy Brief, Center for Studies on Aging, Issue 1. Geneva: United Nations Population Fund; 2009 (http://www.csa org.lb/cms/assets/csa\%20publications/policy\%20briefs\%20 pdfs/csa_policy_brief_issuel_voices_of_the_care_givers.pdf, accessed 27 September 2015).

49. Séoud J, Nehmé C, Atallah R, Zablit C, Yérétzian J, Lévesque $\mathrm{L}$, et al. The health of family caregivers of older impaired per- sons in Lebanon: an interview survey. Int J Nurs Stud. 2007 Feb;44(2):259-72. PMID:16730728

50. Browne CV, Braun KL. Globalization, women's migration, and the long-term-care workforce. Gerontologist. 2008 Feb;48(1):16-24. PMID:18381828

51. Reform of the kafala (sponsorship) system. Policy Brief No. 2. Philippines: Migrant Forum in Asia Secretariat; 2012.

52. Beard JR, Biggs S, Bloom DR, Fried LP, Hogan P, Kalache A, et al. Global population ageing: peril or promise? PGDA Working Paper No. 89. Boston (MA): University of Harvard, Program on the Global Demography of Aging; 2012. 